\title{
The Survival of Escherichia coli sprayed into Air and into Nitrogen from Distilled Water and from Solutions of Protecting Agents, as a Function of Relative Humidity
}

\author{
By C. S. COX \\ Microbiological Research Establishment, Porton Down, nr. Salisbury, Wilts.
}

(Received 5 January 1966)

\begin{abstract}
SUMMARY
The survival in air as a function of relative humidity (RH) and aerosol age is reported for Escherichia coli (strains B and Jepp) and for Serratia marcescens (strain uk 8) sprayed from suspensions in distilled water and in solutions of dextran and of raffinose. The survival in nitrogen $(>99.9 \%)$ of $\boldsymbol{E}$. coli (strains B, Jepp and commune) is given as a function of $\mathrm{RH}$, when sprayed from suspension in distilled water and in raffinose solution. The results show that $\boldsymbol{E}$. coli in the aerosol was subject to at least three stresses, an air stress, an RH stress, and a collection stress. The air stress accounted for loss of viability at low $\mathbf{R H}$ and the $\mathbf{R H}$ stress occured at high $\mathbf{R H}$ and is expressed as RH ranges in which $E$. coli rapidly lost viability. The survival, especially at high $\mathbf{R H}$, depended upon the composition of the collecting fluid. At high $\mathrm{RH}$ a range of $\mathrm{RH}$ was found in which the bacteria were unstable when collected in phosphate buffer. Addition of raffinose (chosen as a typical protecting agent) to the spray fluid and the addition of M-sucrose to the collecting fluid eliminated the instability for $\boldsymbol{E}$. coli (commune) and decreased it for the other two strains.
\end{abstract}

\section{INTRODUCTION}

The survival of bacteria in aerosols has been found to depend upon a large number of factors, including in particular the relative humidity (RH), the nature of the gaseous environment, the solutes in the spray fluid and the collecting fluid. The results of a study of these parameters are presented in this paper. A further paper will describe, by the use of bacteriophage, the influence of $\mathbf{R H}$ and of the gaseous medium upon cell biological processes.

A large number of solutes including sugars, sugar alcohols, amino acids, etc., have been examined for protective action against death in the aerosol. This paper includes the aerosol survival as a function of $\mathrm{RH}$, when two strains of Escherichia coli and one of Serratia marcescens were sprayed from distilled water and from solutions of dextran (molecular weight 115,000) and of raffinose into air, and when three strains of $\boldsymbol{E}$. coli were sprayed from distilled water and from raffinose solution into nitrogen $(>99.9 \%)$. Dextran and raffinose were chosen for this investigation since they form supersaturated solutions and, owing to their molecular size, their location between the cell wall and the droplet/air interface can be fixed. The importance of the distribution of protecting solutes amongst the cell structure has been discussed previously (Cox, 1965). 
The survival characteristics of Escherichia coli (strain Jepp) in the presence of glucose, sucrose, raffinose and dextran were reported previously by $\operatorname{Cox}(1965)$ and in the presence of mannitol and sorbitol by Silver (1965). Webb (1960) and Zimmerman (1962) reported on the protective action of solutes in air, and Hess (1965) studied the effects of oxygen on Serratia marcescens.

\section{METHODS}

\section{Growth of organisms}

Cultures of Escherichia coli (strains B, Jepp and commune) and of Serratia marcescens (strain UK 8), were grown in a $2 \%$ tryptone medium ( $\mathrm{pH} \mathrm{7 \cdot 2)}$ ) for $16 \mathrm{hr}$ at $37^{\circ}$, in shaken flasks technique. Bacteria stored in mother liquor for 4 to 7 days were used in the aerosol studies in air, while $16 \mathrm{hr}$ bacteria were used in the studies in nitrogen.

\section{Preparation of spray suspensions}

Bacterial suspensions in distilled water were prepared from distilled waterwashed slurries of the bacteria. Included in the suspensions were spores of Bacillus subtilis var. niger, so that biological and physical losses could be differentiated (Harper, Hood \& Morton, 1958). Suspensions of spores were obtained from distilled water-washed slurries prepared from spores maintained at $65^{\circ}$ for $30 \mathrm{~min}$. The additions of solutions of dextran and raffinose were made immediately before aerosol generation (Cox, 1965) to give final concentrations of $5 \%(w / v)$ for dextran, and $0 \cdot 13 \mathrm{M}$ and $0 \cdot 3 \mathrm{M}$-raffinose.

\section{Survival estimation}

Estimates of the number of colony-forming units were made by surface drop plates of freshly prepared $1 \%$ tryptone agar in Petri dishes, following suitable dilution of samples containing Escherichia coli or Serratia marcescens and spores. The types of colony were readily counted differentially since $E$. coli formed white colonies, S. marcescens formed red colonies, while Bacillus subtilis formed orange colonies. Each sample was assayed on six tryptone agar plates, usually totalling between 600-1000 colony-forming units for the tracer organism, while the $E$. coli and $S$. marcescens count depended upon the survival in each sample. Since instances of very low survival were anticipated, all diluting and collecting fluids, previously autoclaved, were heated to $65^{\circ}$ for $30 \mathrm{~min}$., and then cooled to room temperature immediately before use, so that the possibility of contamination was minimized. The diluting fluid was phosphate buffer containing $(w / v) \quad \mathbf{0 . 2 4} \%$ $\mathrm{KH}_{2} \mathrm{PO}_{4}, \mathbf{0 . 0 5} \%\left(\mathrm{NH}_{4}\right)_{2} \mathrm{SO}_{4}, 0.05 \% \mathrm{NaCl}, 0.25 \%$ Manucol, Dow-Corning Antifoam $\mathrm{A}$, and $\mathrm{NaOH}$ to $\mathrm{pH} \mathbf{7 \cdot 2}$.

\section{Apparatus}

Suspensions were sprayed by a Collison spray (Green \& Lane, 1957) and the resulting monodisperse aerosol was mixed with a secondary gas supply of controlled temperature and relative humidity (RH). For the experiments in air the diluted aerosol flowed into a static water-jacketed chamber, thermostatically controlled at the temperature of the secondary air supply $\left(21^{\circ} \pm 0 \cdot 1\right)$. For the experiments in nitrogen the diluted aerosol flowed into a $75 \mathrm{l}$. rotating drum container (Goldberg, 
Watkins, Boerk \& Chatigny, 1958) or via a by-pass into a filter system. The apparatus, maintained at 1-2 cm. of water above atmospheric pressure, was installed in a room controlled at $26 \cdot 5 \pm 0 \cdot 2^{\circ}$. The $\mathrm{RH}$ was determined by using a matched set of wet and dry bulb thermometers. Aerosol samples were collected by raised impinger (May \& Harper, 1957) at cloud ages 0 sec., 0.3 sec., 3 sec., 2 min., 5 min., 15 min., $30 \mathrm{~min} ., 31.5 \mathrm{~min} ., 3 \mathrm{hr}$.

\section{De-aeration}

All the bacterial suspensions used for experiments with pure nitrogen as the carrier medium were degassed in a vacuum desiccator and were then raised to atmospheric pressure in pure nitrogen. The air from impingers and collecting fluids was removed by displacement with pure nitrogen.

\section{Collecting fluids}

Collecting fluids of phosphate buffer and of $\mathrm{M}$-sucrose in phosphate buffer were used. Raffinose used as a protective agent in the spray fluid was unsuitable for use in the collecting fluid owing to its low solubility at $26 \cdot 5^{\circ}$.

\section{RESULTS}

\section{Survival in air}

Tables 1 and 2 show the \% aerosol survival as a function of \% $\mathrm{RH}$ when Escherichia coli (в and Jepp) and Serratia marcescens (UK 8) were collected in phosphate buffer and in $\mathbf{M}$-sucrose at cloud ages of 5 and $15 \mathrm{~min}$. based on a time zero sample as $100 \%$ survival. These single results are typical of many determinations made

Table 1. The \% survival of bacteria in air as a function of $\%$ RH at an aerosol age of 5 min.

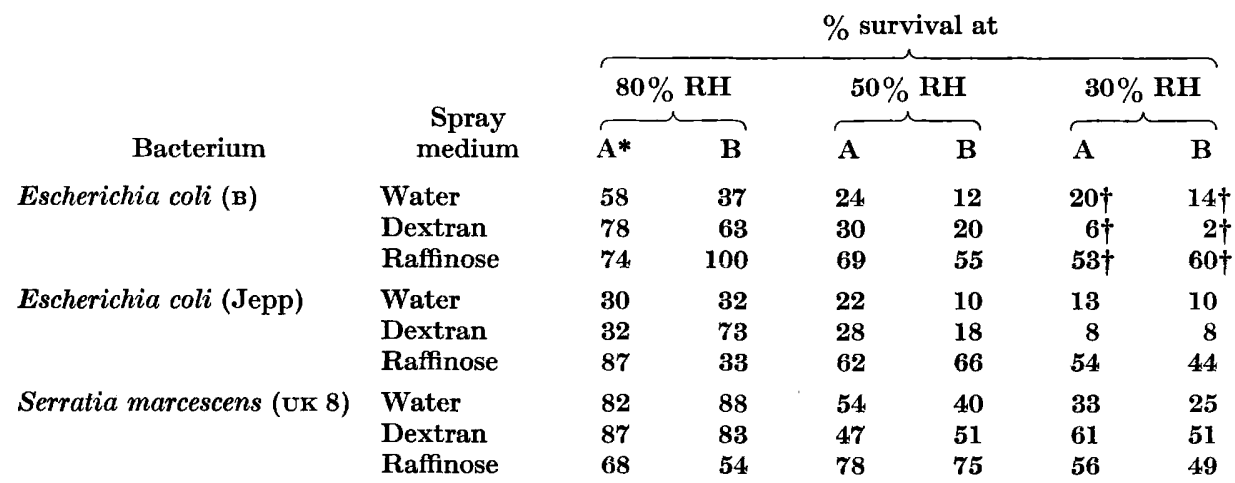

* A, Collected in phosphate buffer alone.

$\mathrm{B}$, Collected in phosphate buffer + M-sucrose. $\dagger=20 \% \mathbf{R H}$.

over a period of years. For aerosols generated from water or dextran solution an overall decrease in viability occurred between 80 and $\mathbf{5 0} \% \mathbf{R H}$, behaviour regarded as typical of Gram-negative bacteria in air. When sprayed from raffinose, however, the pattern of survival varied with the strain being tested and with the 
composition of the collecting fluid. Also, unlike water and dextran, raffinose gave rise to a narrow spread of values of survival at the lower values of RH. Higher viabilities were usually obtained when phosphate buffer alone (low osmotic pressure) was used, rather than when M-sucrose (high osmotic pressure) was used. Exceptions occurred at $80 \% \mathrm{RH}$ when $E$. coli (Jepp) was sprayed from dextran and E. $\operatorname{coli}(\mathrm{B})$ from raffinose.

Compared with water, both dextran and raffinose are seen to protect to various degrees at $80 \% \mathbf{R H}$, but only raffinose shows general protective properties at low RH.

Table 2. The $\%$ survival of bacteria in air as a function of $\%$ RH at an aerosol age of $15 \mathrm{~min}$.

\begin{tabular}{|c|c|c|c|c|c|c|c|}
\hline & & & & $\%$ sur & al at & & \\
\hline & & & & $50^{\circ}$ & $\mathbf{H}$ & $\mathbf{3 0} \%$ & $\mathbf{H}$ \\
\hline Bacterium & medium & A* & $\mathbf{B}$ & $\mathbf{A}$ & B & $\mathbf{A}$ & $\mathbf{B}$ \\
\hline Escherichia coli (B) & Water & $\mathbf{3 5}$ & 28 & $4 \cdot 4$ & $3 \cdot 7$ & $5 \cdot 4 \dagger$ & \\
\hline & Dextran & 84 & 37 & $8 \cdot 3$ & $\mathbf{3} \cdot \mathbf{3}$ & $2 \cdot 1 \dagger$ & $1 \cdot 0$ \\
\hline & Raffinose & 26 & 82 & 61 & 65 & $40 \dagger$ & $\mathbf{3 5 \dagger}$ \\
\hline Escherichia coli (Jepp) & Water & 16 & 14 & 12 & 30 & $7 \cdot 8$ & $7 \cdot 5$ \\
\hline & Dextran & $\mathbf{2 3}$ & 61 & 13 & 10 & $4 \cdot 0$ & $4 \cdot 1$ \\
\hline & Raffinose & 72 & 39 & $\mathbf{5 0}$ & 59 & 36 & 29 \\
\hline Serratia marcescens (UK 8) & Water & 82 & 86 & 42 & 23 & 11 & 9 \\
\hline & Dextran & 80 & 74 & 23 & 22 & 28 & 34 \\
\hline & Raffinose & 94 & 60 & 41 & 46 & 25 & 24 \\
\hline
\end{tabular}

* A, collected in phosphate buffer alone.

$\mathrm{B}$, collected in phosphate buffer plus $1 \mathrm{~m}$-sucrose.

$\dagger=20 \% \mathrm{RH}$.

Table 3. The \% survival of Escherichia coli $($ (в) sprayed from distilled water and stored in air for 30 min., as a function of $\%$ relative humidity (temperature $26.5^{\circ}$ )

$\begin{array}{lcccccc}\text { Relative humidity (\%) } & 90 & 85 & 77 & 65 & 50 & 25 \\ \text { Survival (\%) } & 8 \cdot 6 & 4 \cdot 0 & 10 \cdot 7 & 10.5 & 1 \cdot 3 & 1 \cdot 1 \\ & (10)^{*} & (1 \cdot 3) & (15) & (85) & (37) & (76)\end{array}$

* Values in parentheses are the corresponding \% survival values for bacteria stored in pure nitrogen.

\section{Survival in nitrogen sprayed from distilled water}

Results are presented in Figs. 1-3 as \% survival in pure nitrogen as a function of $\% \mathbf{R H}$ at the various aerosol ages. Survival in nitrogen was related to the ratio of Escherichia coli to tracer in the spray suspension both before and after spraying. Usually these values agreed within $0-5 \%$, the mean being taken to represent $100 \%$.

The air stress

Corresponding curves for the survival in air for $16-\mathrm{hr}$ bacteria are not given since it was observed that the degree of survival was always much less than (low $\mathbf{R H}$ ) or close to (high RH) the degree of survival in nitrogen for otherwise similar conditions. The magnitude of the effect for 16-hr Escherichia coli (в) is indicated by the data of Table 3. 

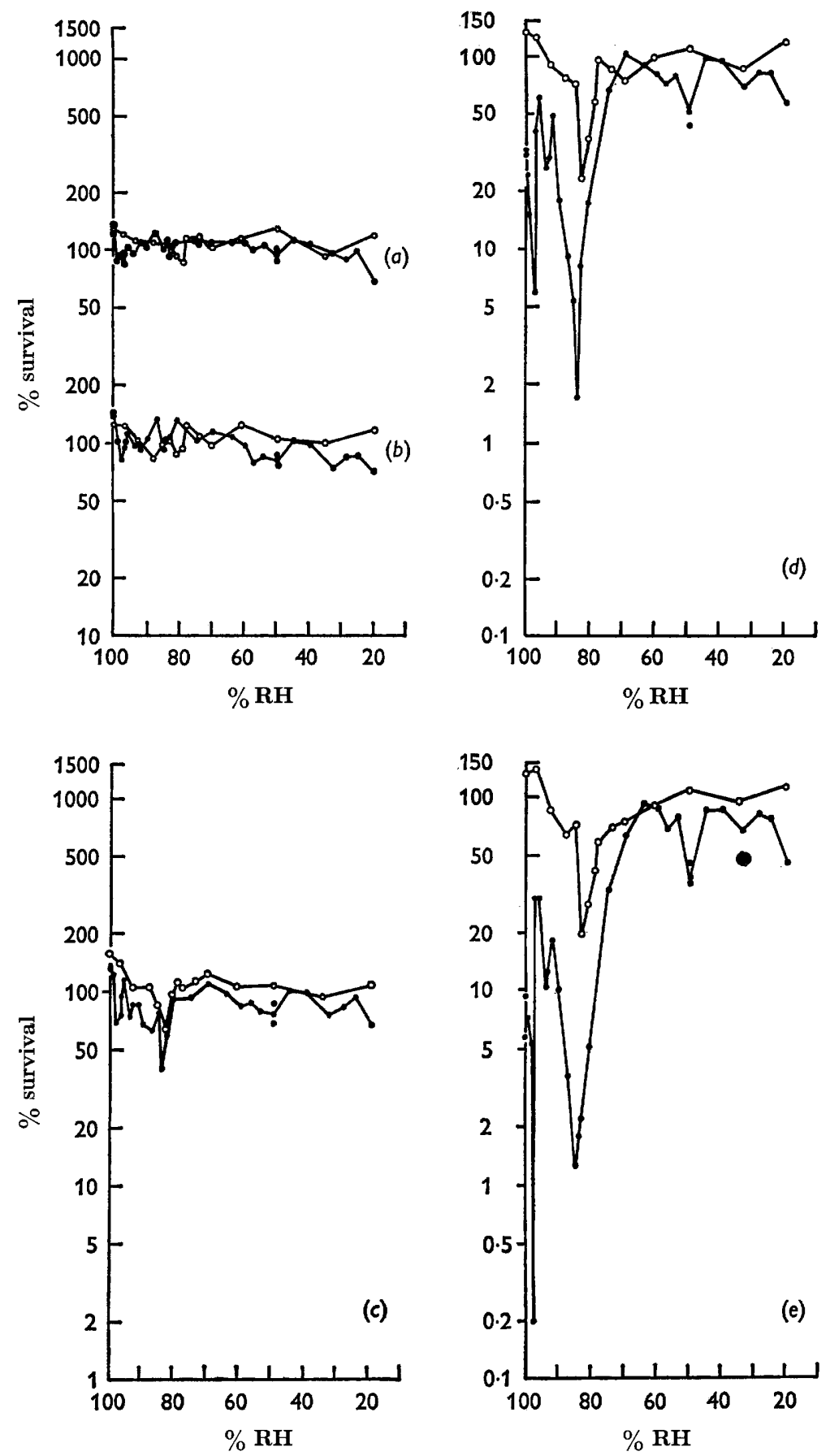

Fig. $1 a-e$. Survival of $E$. coli (B) in nitrogen at aerosol ages of $(a) 0 \cdot 3$ sec., $(b) 3$ sec., $(c)$ 2 min., (d) 15 min., (e) 30 min., collected in phosphate buffer. Sprayed from distilled water. $O$ Sprayed from $0 \cdot 13 \mathrm{~m}$-raffinose solution. 


\section{The RH stress}

At high RH the data show that RH can be of critical importance with regard to the survival of bacteria when sprayed from distilled water (Figs. 1-3), since narrow RH ranges exist where Escherichia coli is particularly unstable. Some regions are of the same order of magnitude as the experimental errors $( \pm 1 \% \mathrm{RH})$ for the determination of $\mathrm{RH}$, which in the main were owing to possible variations in room temperature and to inaccuracies in the assessment of wet bulb depression.
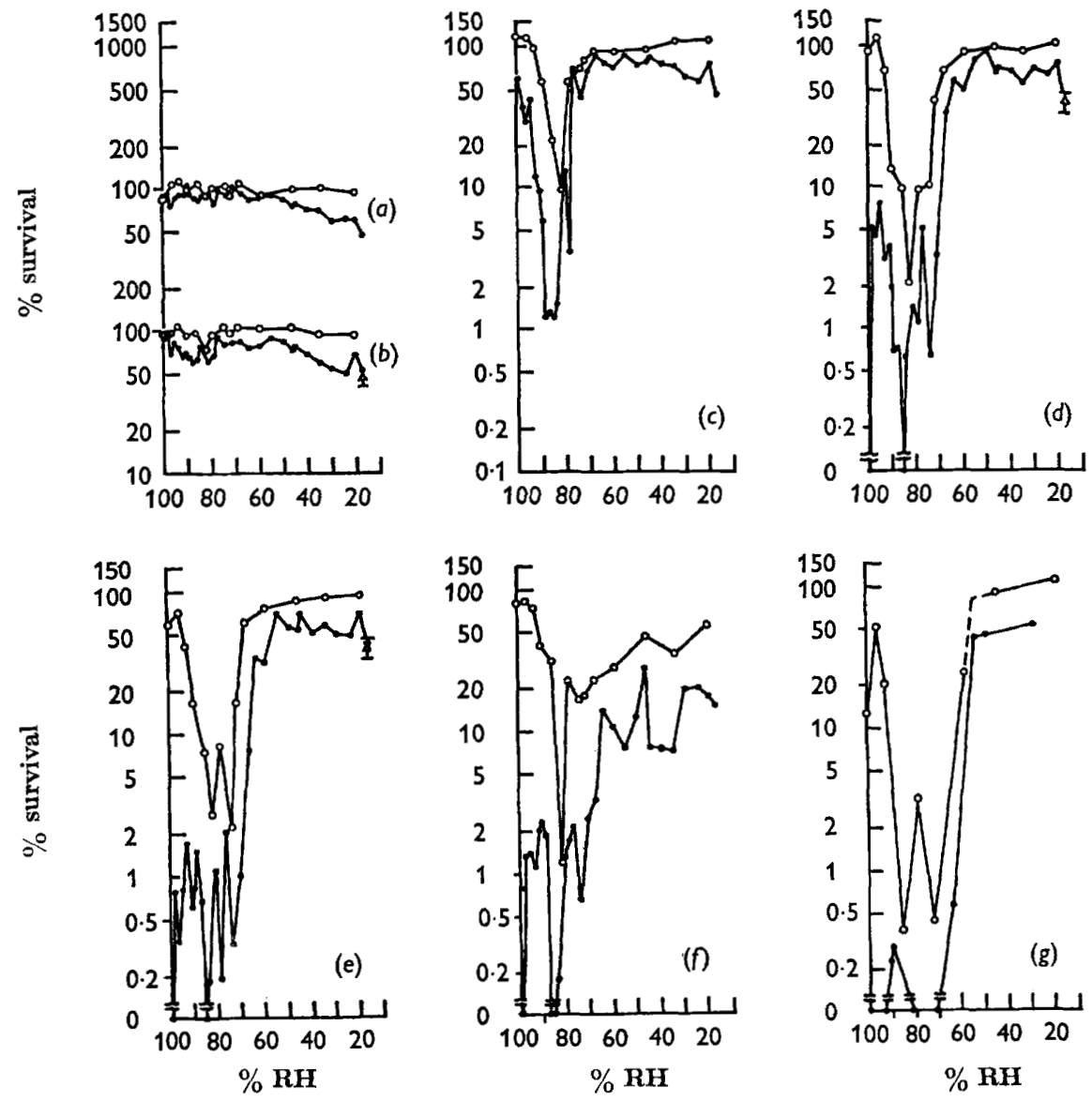

Fig. 2a-g. Survival of $E$. coli (Jepp) in nitrogen at aerosol ages of $(a) 0.3 \mathrm{sec} .,(b) 3$ sec., (c) 2 min., (d) 15 min., (e) 30 min., $(f) 31.5$ min., $(g) 3 \mathrm{hr} .(a)-(e)$ and $(g)$ collected in phosphate buffer, $(f)$ collected in M-sucrose in phosphate buffer. - Sprayed from distilled water. $O$ Sprayed from 0.13 M-raffinose solution. I Arithmetic mean and standard deviation for 14 determinations when sprayed from distilled water.

In high RH conditions periods of an hour were usually required to attain equilibrium throughout the entire apparatus, and so it may be that once equilibrium was established considerable lag occurred for the drum to follow changes of the order of $\pm \mathbf{0 . 2}$ in room temperature. This conclusion is supported by the observa- 
tions that the conditions of humidity in the drum determined after each experiment were the same as those at the onset for each bacterial aerosol generation.

The data of Figs. 1-3 show that at low RH the good stability of Escherichia coli from a $16 \mathrm{hr}$ culture when sprayed from distilled water into nitrogen was not a transient condition, since it was maintained at a cloud age of $3 \mathrm{hr}$. These results contrast with those for 4 to 7 -day-bacteria when sprayed into air (Tables 1 and 2) and stored for up to $15 \mathrm{~min}$. The effect of culture age was examined for 4- to 7-day-old $E$. coli (Jepp), and the results obtained with the aged E. coli (Jepp) bacteria were
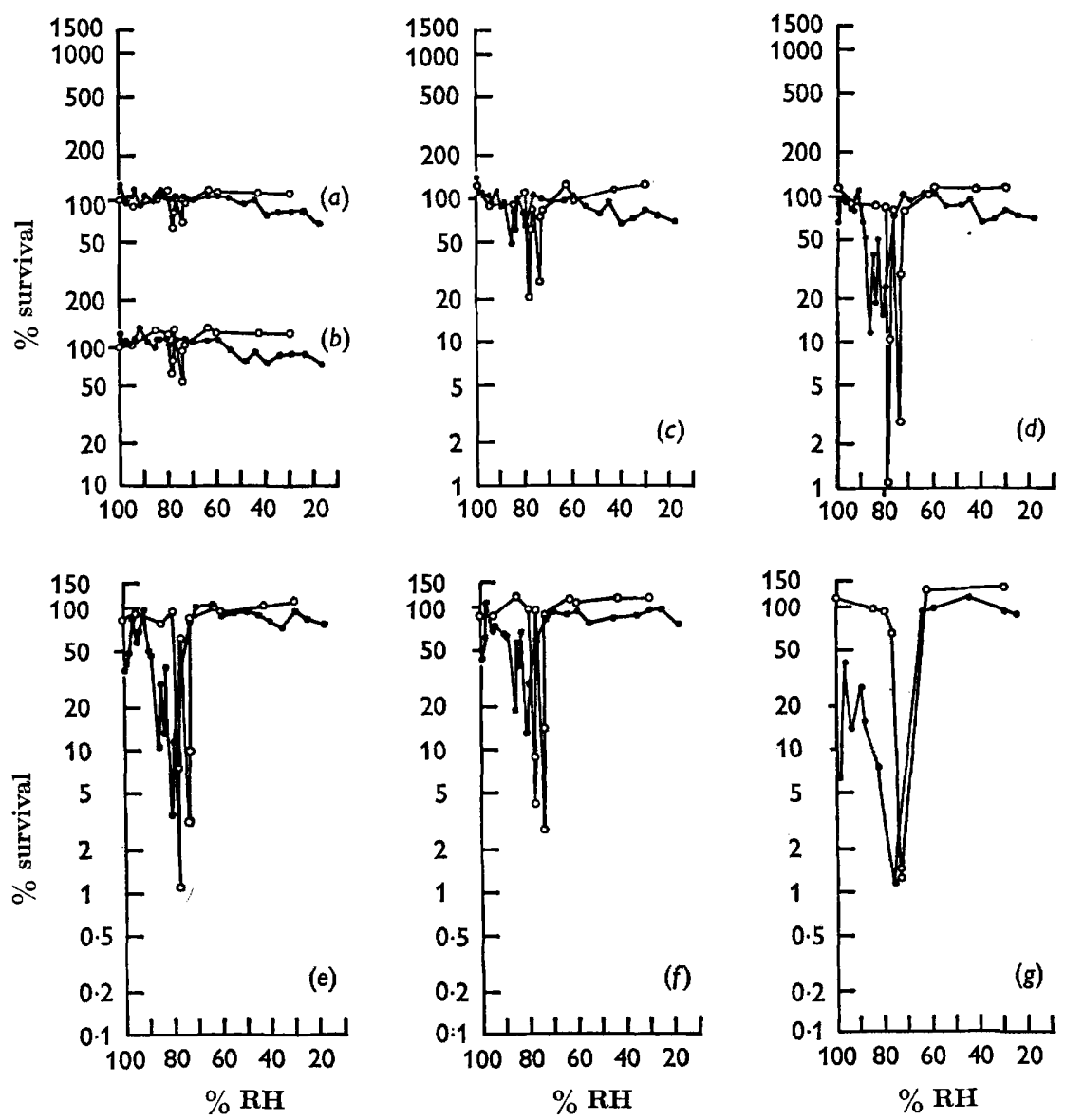

Fig. 3a-g. Survival of $E$. coli (commune) in nitrogen at aerosol ages of $(a) 0 \cdot 3$ sec., (b) 3 sec., $(c) 2$ min., $(d) 15$ min., $(e) 30$ min., $(f) 31.5$ min., $(g) 3 \mathrm{hr} .(a)-(e)$ and $(g)$ collected in phosphate buffer, $(f)$ collected in M-sucrose in phosphate buffer. - Sprayed from distilled water. $O$ Sprayed from $0 \cdot 13$ m-raffinose solution.

similar to those for $E$. coli (B) at a culture age of $16 \mathrm{hr}$, i.e. the degree of survival of $\boldsymbol{E}$. coli (Jepp) at high $\mathbf{R H}$ was quite markedly dependent upon culture age, whereas this effect was not apparent at low RH values.

The manner in which the primary aerosol was mixed with secondary gas flow was found to influence the observed degree of survival. The extent of this influence and 
that of culture age can be estimated from Fig. $2 b-e$ which at $17 \% \mathbf{R H}$ include the survival values for the arithmetic means and the standard deviations of fourteen separate determinations. These determinations were obtained with bacteria from 2 to 7 days old, and with various arrangements for mixing primary aerosol with secondary gas flow. These experimental variations are of minor importance in influencing survival compared with variations of $\mathrm{RH}$ value. Many replicate experiments with $16 \mathrm{hr}$ bacteria at various $\mathrm{RH}$ values, some of which were conducted in a second drum apparatus, showed that the reported results were highly reproducible.
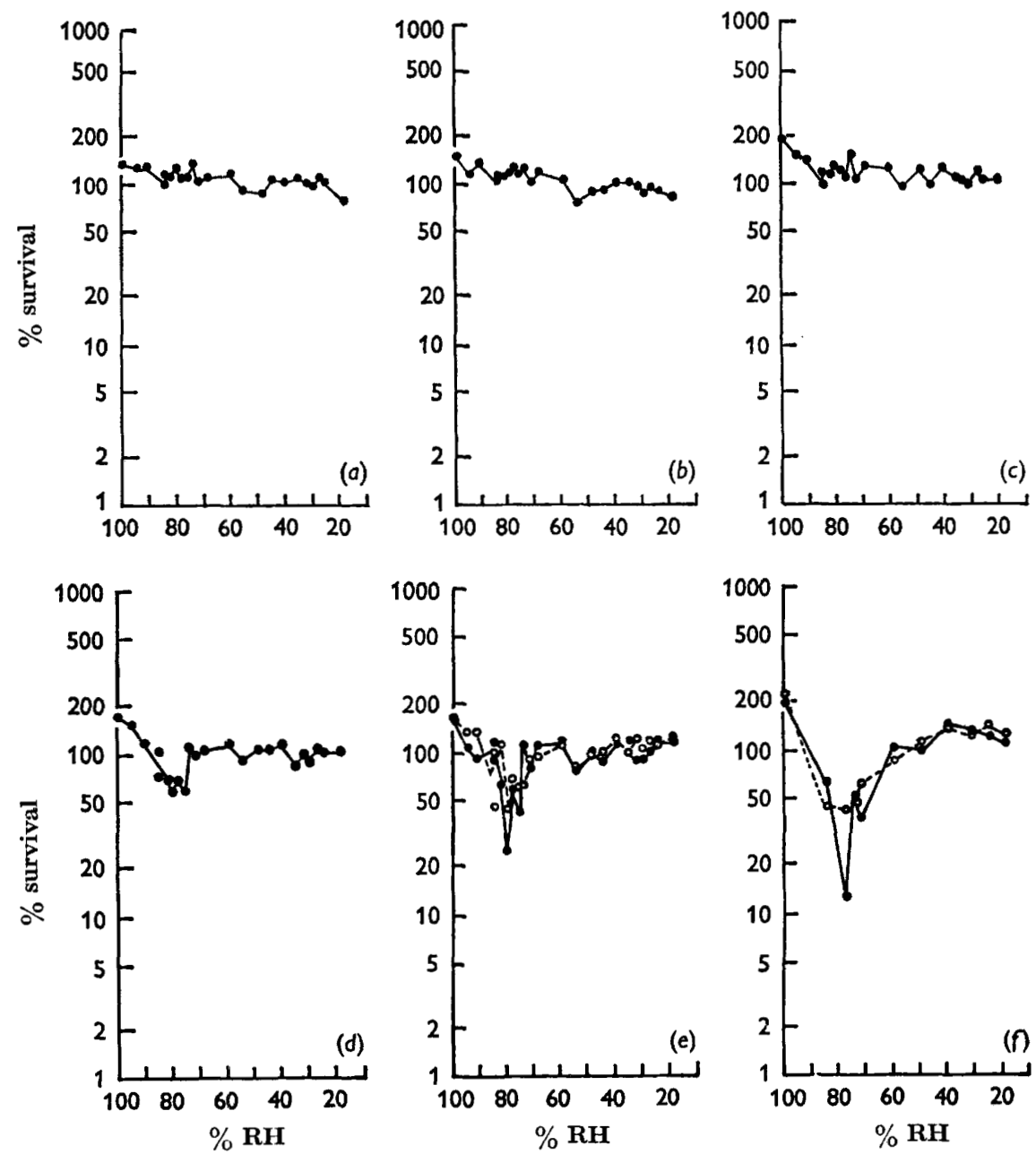

Fig. 4a-f. Survival of $E$. coli (в) in nitrogen sprayed from $0.3 \mathrm{~m}$-raffinose at aerosol ages of (a) 0.3 sec., (b) 3 sec., $(c) 2$ min., $(d) 15$ min., $(e) 30$ min., $(f) 3 \mathrm{hr}$. Collection in phosphate buffer. $O$ Collection in $M$-sucrose.

\section{Collection stress}

For the Jepp and commune strains of Escherichia coli considerable differences between collecting fluids of phosphate buffer and $\mathbf{m}$-sucrose in phosphate buffer are shown by comparison of Figs. $2 e$ and $3 e$ with Figs. $2 f$ and $3 f$, respectively. 
These results show that some biological decay was associated with the collection of these two organisms, the extent depending upon RH. With $E$. coli (в) only minor differences were found for these two collecting fluids.

\section{Survival when sprayed from raffinose solution into nitrogen}

Data are included to show that raffinose in the spray fluid at a concentration of 0.13 M (Figs. 1-3) and at 0.3 M (Figs. 4-6) enhanced the degree of survival of the three organisms. Raffinose was chosen for study of a protective agent since the
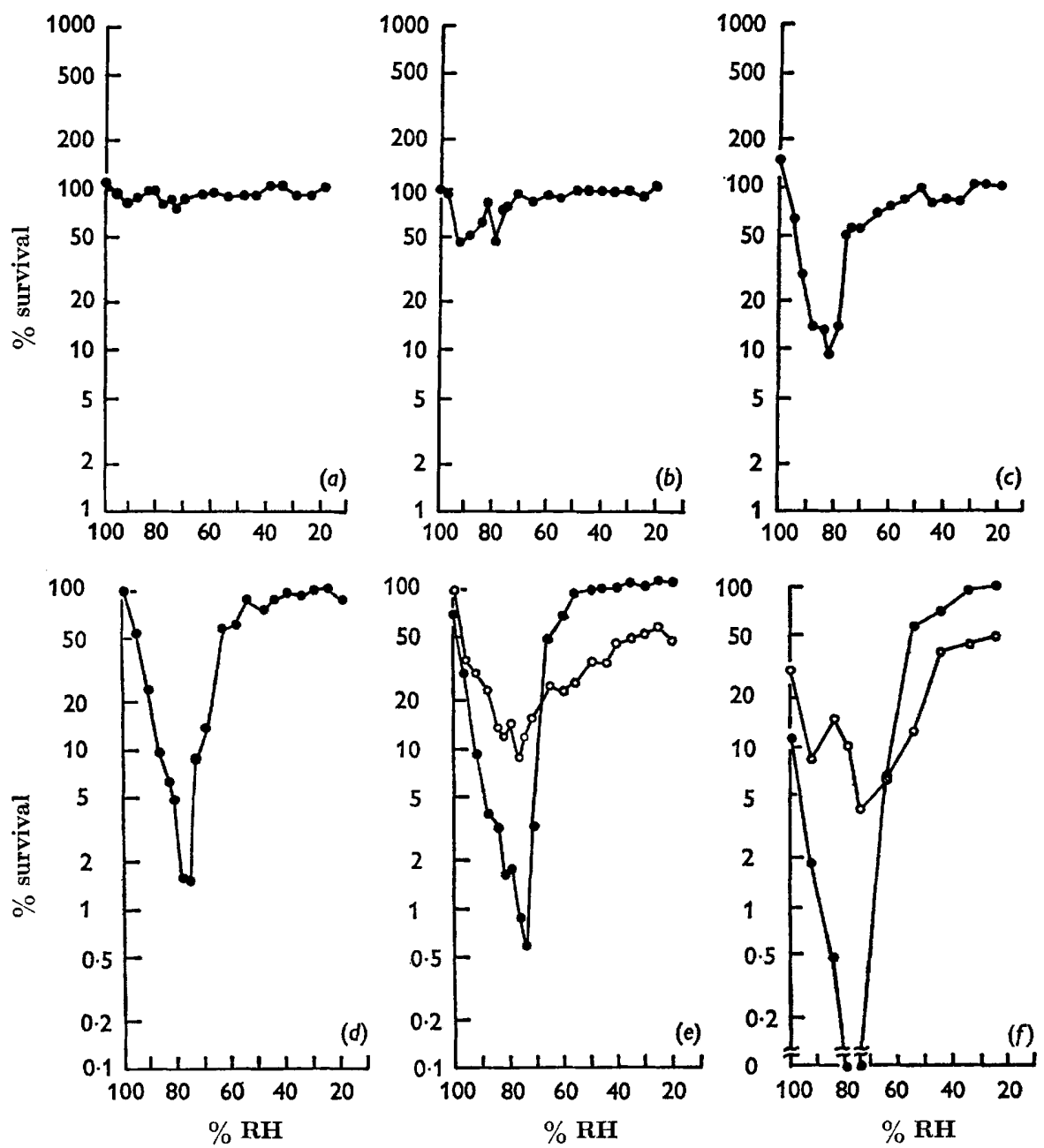

Fig. $5 a-f$. Survival of $E$. coli (Jepp) in nitrogen sprayed from $0 \cdot 3$ m-raffinose at aerosol ages of $(a) 0.3$ sec., $(b) 3$ sec., $(c) 2$ min., $(d) 15$ min., $(e) 30$ min., $(f) 3 \mathrm{hr}$. $\bullet$ Collection in phosphate buffer. $O$ collection in $M$-sucrose.

results in air suggested it to be one of the best protective agents and also because it does not readily permeate the cell wall, hence simplifying the experimental technique and the interpretation of results. The technique whereby the protective agent is confined to outside the cell wall has been previously discussed (Cox, 1965). 


\section{Survival of Escherichia coli (strain $B$ )}

Figure 4 shows how the marked minimum between 70 and $85 \%$ RH developed with aerosol age. Comparison with Fig. 1 suggests that raffinose in the spray fluid prevented the appearance of, or caused a shift in the position of, the minima. For an aerosol generated from distilled water they occurred at $100,97,85$ and $50 \% \mathbf{R H}$, from $0 \cdot 13 \mathrm{M}$-raffinose it occurred at $83 \% \mathbf{R H}$, and from $0.3 \mathrm{M}$-raffinose at $80 \% \mathbf{R H}$.
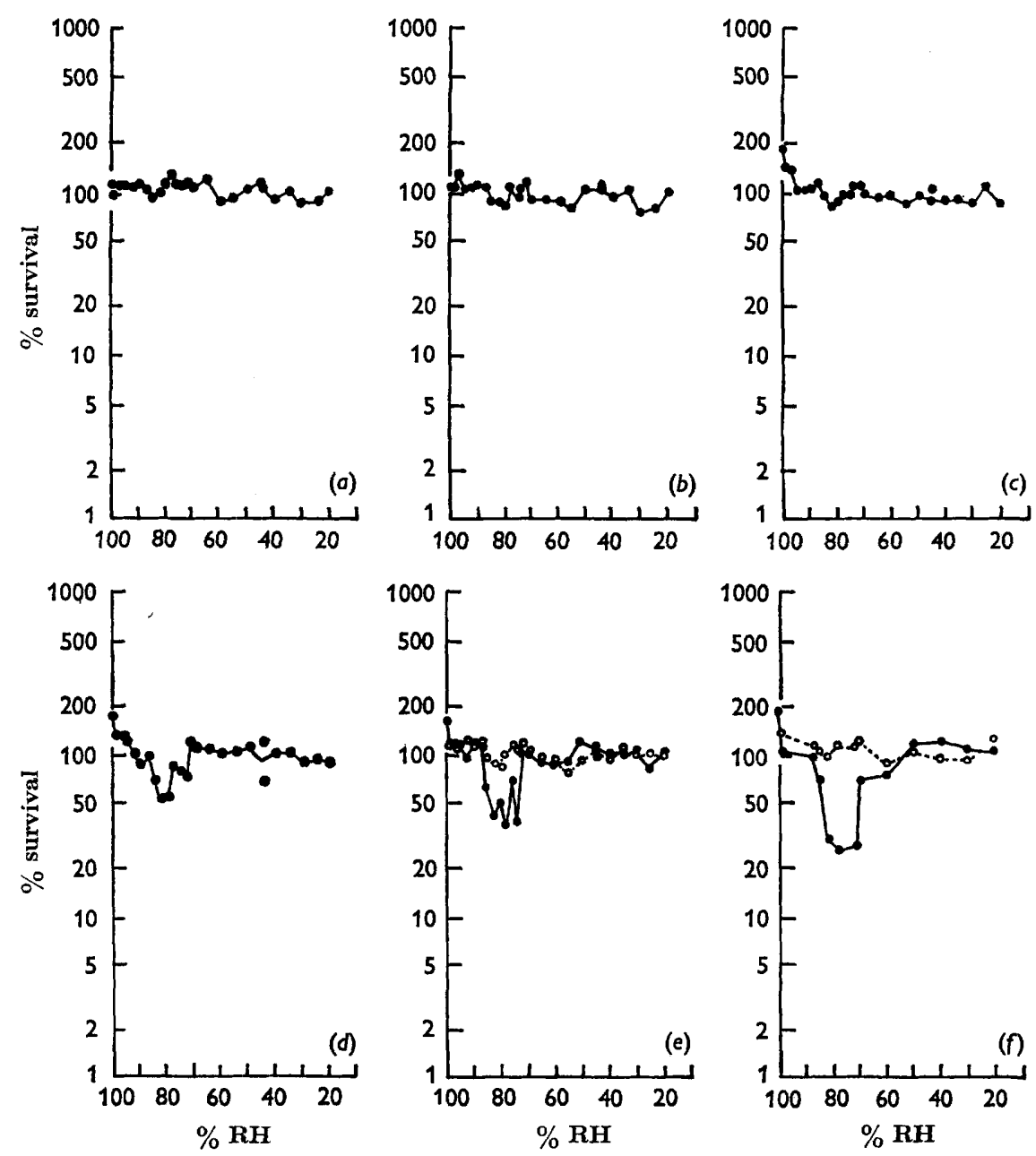

Fig. 6a-f. Survival of $E$. coli (commune) in nitrogen sprayed from 0.3 M-raffinose at aerosol ages of $(a) 0.3 \mathrm{sec} .,(b) 3 \mathrm{sec} .,(c) 2 \mathrm{~min} .,(d) 15 \mathrm{~min} .,(e) 30 \mathrm{~min} .,(f) 3 \mathrm{hr}$. Collection in phosphate buffer. $\bigcirc$ Collection in $M$-sucrose.

Thus the addition of raffinose to the spray fluid caused the disappearance of minima at 100, 97 and $50 \% \mathrm{RH}$. The difference between 85 and $83 \%$ may not be real, and the difference between 83 and $80 \%$ is only just outside the experimental error, but 85 and $80 \%$ appear to be different. 
Similarly, as when sprayed from $0 \cdot 13 \mathrm{M}$-raffinose, Fig. $4 e$ and $f$ indicate that the survival of Escherichia coli (B) when sprayed from $0.3 \mathrm{M}$-raffinose in the range 70$85 \%$ RH was dependent upon the collecting fluid, since better survival was obtained usually for collection in $\mathbf{M}$-sucrose in buffer than in phosphate buffer alone. The collection difference appeared to be quite critically dependent upon the RH at which the aerosol was stored. Inferior survival was obtained (Fig. 4) at $\mathbf{7 4} \%$ RH, but better survival at 76, 80, 82 and $91 \%$ for collection in $\mathrm{M}$-sucrose rather than in buffer alone; at other RH values little or no difference was found between the two collecting fluids, both of which gave good survival. Hence, in the critical region between 70 and $85 \% \mathbf{R H}$ at least a part of the survival loss occurred during or following collection, rather than in the aerosol state. At RH values outside the critical region good survival of $\boldsymbol{E}$. coli (в) was obtained for raffinose-protected bacteria at aerosol ages up to $3 \mathrm{hr}$ (Fig. $4 \mathrm{f}$ ).

\section{Survival of Escherichia coli (strain Jepp)}

In Fig. 5 the minimum is seen to develop at $74 \% \mathbf{R H}$ during an aerosol aging of 30 min. At earlier aerosol ages the position of the minimum occurred at higher RH values, while by $3 \mathrm{hr}$ a zone of zero survival extended from 74 to $79 \% \mathrm{RH}$, for collection in phosphate buffer. When compared with Fig. 2 Escherichia coli (Jepp) sprayed from distilled water exhibited a broad instability zone extending from $\mathbf{5 5}$ to $100 \% \mathbf{R H}$ with minima at 74, 79, 85 and $100 \% \mathrm{RH}$. When sprayed from $0 \cdot 13 \mathrm{M}-$ raffinose solution minima occurred at 74,82 and $100 \% \mathrm{RH}$, but when sprayed from 0.3 M-raffinose solution a minimum was detected at $74 \% \mathbf{R H}$ only (Fig. 5).

Figures $2 e, f, 5 e$ and $f$ show that like Escherichia coli (в), the survival of $\boldsymbol{E}$. coli (Jepp) sprayed from raffinose solution was dependent upon the collecting fluid, M-sucrose being superior to phosphate buffer over the range of from 67 to $100 \%$ RH. The instability of $\boldsymbol{E}$. coli (Jepp) shown over this range happened at least in part at or following collection. Over the range of from 20 to $55 \% \mathrm{RH}$ good survival was obtained, demonstrating that even in the presence of a protecting agent, $\boldsymbol{E}$. coli (Jepp) is unstable at high RH and stable at low RH. Similarly, to aerosols generated from distilled water and $0.13 \mathrm{M}$-raffinose, the stability at low $\mathbf{R H}$ was again dependent upon the collecting fluid, since survival in $\mathbf{M - s u c r o s e}$ in phosphate buffer was inferior to that of phosphate buffer alone for bacteria sprayed from 0.3 M-raffinose. The cross-over point at which the reversal occurred was at $70 \%$ $\mathbf{R H}$ for $\boldsymbol{E}$. coli (Jepp) sprayed from distilled water (Fig. $2 e$ and $f$ ) and $\mathbf{0 \cdot 1 3} \mathrm{M}$ raffinose (Fig. $2 e$ and $f$ ), and at $67 \% \mathbf{R H}$ when sprayed from $0 \cdot 3 \mathrm{M}$-raffinose (Fig. $5 c$ and $f$ ). Hence survival at low $\mathbf{R H}$ was also dependent upon collection, with a loss of viability taking place during or following collection in $\mathbf{M}$-sucrose in phosphate buffer.

\section{Survival of Escherichia coli (strain commune)}

Figure 6 indicates how the instability zone extending from 72 to $87 \%$ RH deepened as the aerosol aged, while the survival at other RH values was maintained at close to the initial values. These data compared with those of Fig. 3 suggest that the addition of raffinose to the spray fluid caused a shift of the instability zone to lower RH. 0.13 M-raffinose resulted in minima occurring at 74 and $78 \% \mathbf{R H}$ 
compared to minima at 81, 84, 86, 95 and $100 \% \mathrm{RH}$ for an aerosol generated from distilled water. Also the width of the broad instability zone for such raffinose protected bacteria extended from 73 to $80 \% \mathrm{RH}$, as opposed to 70 to $92 \%$ for nonprotected bacteria. 0.3 M-raffinose in the spray fluid produced minima at 74 and $78 \% \mathbf{R H}$ with an instability zone extending from 72 to $87 \% \mathbf{R H}$, i.e. a reversal of the narrowing observed for $0.13 \mathrm{M}$-raffinose in the spray fluid. It would seem therefore that the effect of raffinose upon the width of the instability zone was not progressive with raffinose concentration in the spray fluid.

Figures $3 e, f, 6 e, f$ demonstrate that similarly to the behaviour of Escherichia coli (B and Jepp), the survival of $E$. coli (commune) in the 72 to $87 \% \mathbf{R H}$ region was markedly dependent upon the collecting fluid, in that $\mathrm{M}$-sucrose in buffer was superior to phosphate buffer alone. The degree of this difference when sprayed from $0 \cdot 3 \mathrm{M}$-raffinose appeared to be related to aerosol age since at $\mathbf{3 0} \mathrm{min}$., collection in $\mathrm{m}$-sucrose gave survival slightly less than $100 \%$ at $80 \% \mathrm{RH}$, while at $3 \mathrm{hr}$ complete survival was apparently obtained in the unstable region (Fig. $6 e$ and $f$ ). Therefore for $E$. coli (commune) the instability zone extending from 72 to $87 \% \mathbf{R H}$ seems to be the result of collecting in phosphate buffer. This survival loss must have happened during or following collection rather than in the aerosol state, since the bacteria were alive when collected in $\mathbf{M}$-sucrose in buffer. The results suggest that good survival of $E$. coli (commune) can be achieved over the range $\mathbf{R H ~ 2 0 - 1 0 0 \%}$ at an aerosol age of $3 \mathrm{hr}$.

\section{DISCUSSION}

The results show that Escherichia coli in an aerosol is subject to at least three stresses, viz. an air stress, an $\mathrm{RH}$ stress and a collection stress. The air stress accounts for the loss of viability at low $\mathrm{RH}$, while the RH stress occurs at high $\mathbf{R H}$ and is expressed as $\mathbf{R H}$ zones in which $\boldsymbol{E}$. coli rapidly loses viability. All three stresses are modified by the presence and nature of the protective agent.

\section{The air stress}

The effect of air upon the survival of bacteria has been reported previously for freeze-dried organisms (Bateman, McCaffrey, O'Connor \& Monk, 1961; Lion, 1963) while for bacteria in aerosol Webb (1959) found no difference between the survival in air and that in other gases. The three strains of Escherichia coli examined here showed survival values in air similar to (high $\mathbf{R H}$ ) or much less than (low $\mathbf{R H}$ ) those in pure nitrogen $(>99.9 \%)$. The magnitude of the effect is indicated by the data of Table 3, which gives the $30 \mathrm{~min}$. survival values of $E$. coli (B) (16 hr cultures), in air and in nitrogen, as a function of RH. The effect of culture age was that aged bacteria were more stable than fresh ones.

The action of the protective agents tested was such that, compared with distilled water, dextran protected Escherichia coli at high but not at low $\mathrm{RH}$, while raffinose enhanced survival at all three relative humidities. Raffinose decreased but did not eliminate the loss of viability in air and the pattern of survival was unchanged in that survival remained greatest at the highest $\mathrm{RH}(80 \%)$. 


\section{The RH stress}

Loss of spore tracer. Experiments have shown that trends suggested by the figures for survival versus $\mathrm{RH}$ at aerosol ages of 0.3 and $3 \mathrm{sec}$. became more marked as the aerosol aged. The possible exceptions were for survival at saturated conditions, when viabilities in excess of $100 \%$ were apparently achieved at the shorter aerosol ages. These high values can be attributed to differential loss (physical or biological) of tracer, or to division of Escherichia coli, since microscopical examination of spray suspensions, and of aerosol clouds collected by slit sampler (Bourdillon, Lidwell \& Thomas, 1941), suggested that it was not a de-clumping phenomenon. Using various techniques it has been demonstrated that Bacillus subtilis var. niger spores lose viability when dispersed at very high $\mathrm{RH}$; the extent of the loss is variable from batch to batch, and while some spores rapidly became non-viable, others showed marked sensitivity to heating at $60^{\circ}$ (Drs Anderson, Harper and Hood, personal communications). Survival curves show the stability of $\boldsymbol{E}$. coli relative to that of spores and, in essence, the loss of spore viability, when it occurred, caused the $\boldsymbol{E}$. coli degree of survival to be overestimated. Spores of $B$. subtilis var. niger and vegetative organisms of $\boldsymbol{E}$. coli both tend to be unstable at high $\mathbf{R H}$ values. The interpretation of results is in no way invalidated by this difficulty because viable decay of $B$. subtilis var. niger ceased after $2 \mathrm{~min}$. in the aerosol and results are therefore comparatively if not absolutely valid.

Table 4. Evaporation times for water droplets in a polydisperse aerosol at $20^{\circ}$ and $100 \%$ relative humidity

$\begin{array}{cr}\underset{(\mu)}{\operatorname{Diameter}} & \begin{array}{r}\text { Time } \\ (\mathrm{sec})\end{array} \\ \mathbf{2} & \mathbf{0 . 5 6} \\ \mathbf{4} & \mathbf{4 . 5 0} \\ \mathbf{8} & \mathbf{3 5 . 9 6}\end{array}$

Loss of viability at saturation for organisms sprayed from distilled water. The osmotic pressure inside these Escherichia coli organisms is of the order of 6 atmospheres, comparing with the value of 2-3 atmospheres reported by Mitchell \& Moyle (1956), and the water activity equivalent to this pressure is 0.996 , i.e. less than the value of 1.000 of the vapour phase which should be achieved in a saturated state. In these conditions no water should leave the cytoplasm; yet $\boldsymbol{E}$. coli was often highly unstable at saturation when sprayed from water (Figs. 1-3). Owing to the enhanced vapour pressure over an aerosol droplet surface, the water of the droplet will evaporate even in saturated air through isothermal distillation. Green \& Lane (1957) give the evaporation times as in Table 4. In practice these times may be slightly greater than the calculated values which do not allow for the very slight cooling caused by evaporation. Hence, the opportunity exists for mechanisms such as surface denaturation or phase separation, as has been suggested previously (Cox, 1965). Bacteriophage has been shown to be inactivated by a process of this kind (Adams, 1948).

Loss of viability at less than saturation for organisms sprayed from distilled water. At $\mathbf{R H}$ values lower than saturation other unstable regions existed for organisms 
sprayed into nitrogen, occur mainly in the 70-100\% region. Instability has been reported for Serratia marcescens in the freeze-dried state at about 94\% $\mathbf{R H}$ (Monk \& McCaffrey, 1957; Bateman, et al. 1961) and in the aerosol state in air at 45-60\% RH (Dr R. L. Dimmick, personal communication) and for dried Escherichia coli in vacuo at high RH (Davis \& Bateman, 1960; McDade \& Hall, 1964). Owing to the critical nature of the response it is not known if the minima extend to $0 \%$ survival or the maxima to $100 \%$. Zones so narrow that they were not detected may exist; such a possibility is suggested by the apparently critical minima for $E$. coli (в and commune) (e.g. Figs. $1 e$ and $3 e$ ).

\section{The collection stress}

The influence that the composition of the collecting fluid has on the level of survival of bacteria recovered from aerosols is partly owing to the distribution of solute throughout the organism. Collecting fluids of high osmotic pressure are required (Cox, 1963) when protective agents are present intracellularly, in order to prevent osmotic lysis. In the experiments reported here, when sprayed from distilled water or where spray fluid solutes were extracellular, osmotic lysis during collection would be expected to be trivial. But should it occur under these conditions, then the lower the RH the greater should be the lytic effect, because as the RH decreases so the concentrations of solutes in the evaporated droplets increase. However, the lytic effect was not greater at the lower $\mathrm{RH}$ values since the presence of $\mathrm{M}$-sucrose in the collecting fluid did not enhance the degree of survival over that of phosphate buffer alone. This confirms that the effects observed were consistent with the spray fluid solutes being extracellular for experiments in air and in nitrogen. Microscopical examinations of samples collected by slit sampler (Bourdillon et al. 1941) support an explanation other than that of osmotic lysis. Other explanations for the effect of the collecting fluid have been made previously (Cox, 1965). The phenomenon demonstrates that in certain conditions part of the survival loss can be attributed to collection.

\section{The action of protecting agents}

The results demonstrated that Escherichia coli (в, Jepp and commune) sprayed from distilled water into nitrogen atmospheres were more stable at low $\mathbf{R H}$ than at high $\mathrm{RH}$. The addition of raffinose to the spray fluid has not altered this overall conclusion. The action of raffinose located outside the cell wall, whilst enhancing the survival at low RH to a slight degree, mainly took effect at high $\mathbf{R H}$ in causing slight shifts in the position of, or in causing the elimination of, minima in the survival versus $\mathrm{RH}$ curves, and in altering the width and perhaps the intensity of these unstable zones. In the case of $E$. coli (commune) raffinose located outside the cell wall prevented the occurrence of the instability zone when the organisms were collected in $\mathbf{M}$-sucrose in buffer.

One of the obvious effects of the addition of raffinose is that the particle size distribution was altered. The particle size distributions for aerosols generated from distilled water, $0.13 \mathrm{M}$-raffinose and $0.3 \mathrm{~m}$-raffinose were determined by using a modified Andersen sampler (May, 1964). The results did suggest that a slight shift to larger particle sizes was caused by the addition of raffinose, but in stored aerosols the differences between those generated from $0 \cdot 13 \mathrm{M}$ and $0 \cdot 3 \mathrm{M}$-raffinose were 
negligible. At very short aerosol ages (3 sec.) a slightly greater shift was observed for 0.3 than for $0.13 \mathrm{M}$-raffinose. Therefore if the action of raffinose is through an altered particle size distribution then the very early life history of aerosol particles must influence the survival of bacteria contained within them, even after $3 \mathrm{hr}$ aerosol storage. Another possibility is that in the short time between the addition of raffinose to the bacteria and aerosol generation, some change in the state of the bacteria occurred, possibly caused by the different water activities of the spray fluids.

A further action of raffinose might be through modified rates of water evaporation, or rehydration on collection, as previously suggested (Cox, 1965). However, this would now seem unlikely for the conditions of the present experiments, unless the rate of evaporation was so critical that lethality existed only at the $\mathrm{RH}$ of the mimima. Furthermore, since for a stored aerosol the particle size distributions of aerosols generated from 0.13 and $0.3 \mathrm{M}$-raffinose were identical, it is extremely difficult to see why the rates of rehydration of the particles of these two aerosols should differ. Yet for Escherichia coli (commune) it was shown that 0.3 M, but not $0.13 \mathrm{M}$-raffinose did protect the bacteria provided that a collecting fluid of $\mathbf{M}$ sucrose in phosphate buffer was used. This means that bacteria collected in phosphate buffer lost viability during or following collection. Does the protecting agent in the critical RH zone therefore operate during collection and to an enhanced degree with a collecting fluid of $\mathrm{M}$-sucrose? This may possibly be so for aerosols generated into atmospheres of nitrogen, but for aerosols generated into air at low RH when the stress operates in the aerosol state, the protective agent must be effective additionally either by forming a viscous layer or as a non-volatile solvent, as discussed later.

Since all three strains of Escherichia coli appear to be unstable, even in the presence of raffinose, in the region of high $\mathbf{R H}$ when collected in buffer, perhaps the same phenomenon is responsible for their loss of viability. For $E$. coli (commune) it was found that the instability disappeared for collection in $\mathbf{M -}$ sucrose. $\boldsymbol{E}$. $\operatorname{coli}$ (в and Jepp) demonstrated superior survival in this $\mathrm{RH}$ region when collected in the sucrose as opposed to the phosphate collecting fluid. Therefore at least part and perhaps all loss of viability in this region happened during or following collection, rather than while the bacteria were in the aerosol state. As discussed, this collection phenomenon does not appear to be caused by osmotic lysis of the cells on collection in fluids of low osmotic pressure.

The mode of the protective action of raffinose is not certain, but it appears to be interrelated to the mode of action of the collecting fluid, and is effective with raffinose outside the cell wall. Owing to this location of raffinose, it may operate as a constituent (of rapidly changing concentration) of the collecting fluid. Good protecting agents for Escherichia coli must have at least two mechanisms of action. First, they must prevent or slow down the rate of loss of viability caused by the toxic action of air, and secondly, they must prevent or slow down the rate of loss of viability within critical $\mathrm{RH}$ ranges. Protective agents such as raffinose decrease rather than eliminate the biological decay rate for bacteria sprayed into air (Cox, 1963). They may operate by forming a highly viscous layer between the cell wall and its environment, hence slowing the rate of access of, for example, oxygen to the bacterium, or by behaving as a non-volatile solvent for structures in the region of the cell wall which only become labile to air when drying-out occurs. Since rapid 
shaking in air of suspensions of $\boldsymbol{E}$. coli has little or no effect on survival and since air is more toxic at low than at high $\mathrm{RH}$, the latter explanation of an action of protective agents seems to be supported. The effect of $\mathrm{RH}$ upon the toxic action of air for freeze-dried Serratia marcescens has been reported by Bateman et al. (1961).

The sensitivity to high $\mathbf{R H}$ was modified by the addition of raffinose to the spray fluid. The results obtained with Escherichia coli (в, Jepp and commune) suggest that at least one action of raffinose was to narrow the RH range of instability. The effect seems to occur through a lowering of decay rate, together with shifts in value for the critical RH ranges, rather than their elimination. It is now to be expected that the true response of survival as a function of $\mathrm{RH}$ will be apparent only when $\boldsymbol{E}$. coli is sprayed from distilled water into nitrogen or other inert gas phase, since the presence of air causes a loss of viability and since protective agents such as raffinose tend to slow the rate of decay caused by both air and loss of water.

The critical nature of the response of survival as a function of $\mathrm{RH}$ has been explained previously in terms of a hygroscopic substance which achieves toxic concentration at the minimum in the survival versus $\mathrm{RH}$ curves (Monk, McCaffrey \& Davis, 1957; Bateman et al. 1961). At RH values lower than the value corresponding to the minimum it was assumed that the substance was insoluble. Since more than one RH minimum has now been shown, then more than one substance having this mode of action needs to be postulated. The collection stress does not seem to support this theory. An alternative explanation is possible in terms of the formation of hydrates of key biological molecules (Falk, Hartman \& Lord, 1962, 1963 $a, b$; Falk, 1964) with some hydrates being formed in a semi-reversible manner, while another is that enzyme activation may occur at certain $\mathrm{RH}$ values. This type of behaviour has been demonstrated (Couper, Eley \& Hayward, 1955).

The occurrence of instability zones may explain reports (Leach \& Scott, 1959; Silver, 1963) of the influence of rehydration rate, since as well as the possibility of spheroplast formation (Record, Taylor \& Miller, 1962; Cox, 1963), the opportunity for an organism to be exposed to a lethal $\mathrm{RH}$ range will depend upon the rate and extent of rehydration and of dehydration. For appreciable decay to occur at high RH, maintenance for several minutes at a critical RH seems necessary; but if the mechanism of loss of viability with regard to time is such that the minima widen, rather than increase in intensity, then complete loss of viability may be rapidly achieved at certain super-critical $\mathbf{R H}$ values. Slow rates of dehydration and rehydration then becomes optimum for the chance exposure of bacteria to these values.

The author thanks Mr I. H. Silver for his interest and for much helpful discussion and thanks Mr M. C. Aireton for technical assistance.

\section{REFERENCES}

Adams, M. H. (1948). Surface inactivation of phage and proteins. J. gen. Physiol. $31,417$.

Bateman, J. B., McCaffrey, Patricia A., O'Connor, R. J. \& Monk, G. W. (1961). Relative humidity and killing of bacteria: the survival of damp Serratia marcescens in air. Appl. Microbiol. 9, 567.

Bourdillon, R. B., Lidweld, O. M. \& Thomas, J. C. (1941). A slit sampler for collecting and counting airborne bacteria. J. Hyg., Camb. 41, 197.

Couper, A., Eley, D. D. \& Haywa RD, A. (1955). Hydrogen activating enzymes of bacteria. The physical chemistry of enzymes. Discuss. Faraday Soc. 20, 174. 
Cox, C. S. (1965). The mode of action of protecting agents. 1st int. Symp. on Aerobiology, published by the Naval Biological Laboratories, Navy Supply Centre, Oaklands, California, U.S.A.

Davis, M. S. \& Bateman, J. B. (1960). Relative humidity and the killing of bacteria. 1. Observations on $\boldsymbol{E}$. coli and $\boldsymbol{M}$. lysodeikticus. J. Bact. 80, 577.

FALK, M. (1964). The ultra-violet spectra of native and denatured deoxyribose nucleic acid. J. Am. chem. Soc. 86, 1226.

Falk, M., Hartman, Jun., K. A. \& Lord, R. C. (1962). Hydration of deoxyribose nucleic acid. I. A gravimetric study. J. Am. chem. Soc. 84, 3843.

Falk, M., Hartman, Jun., K. A. \& Lord, R. C. (1963 $a$ ). Hydration of deoxyribose nucleic acid. II. An infrared study. J. Am. chem. Soc., 85, 387.

Falk, M., Hartman, Jun., K. A. \& Lord, R. C. (1963b). Hydration of deoxyribose nucleic acid. III. A spectroscopic study of the effect of hydration on the structure of deoxyribose nucleic acid. $J$. Am. chem. Soc. 85, 391.

Goldberg, L. J., Watkins, H. M. S., Boerke, E. E. \& Chantigny, M. A. (1958). The use of a rotating drum for the study of aerosols over extended periods of time. $A m . J$. Hyg. 68, 85.

Green, H. L. \& Lane, W. R. (1957). Particulate Clouds : Dusts, Smokes and Mists. London: E. and F. N. Spon Ltd.

Harper, G. J., Hood, A. M. \& Morton, J. D. (1958). Airborne micro-organisms: a technique for studying their survival. J. Hyg., Camb. 56, 364.

Hess, G. E. (1965). Effects of oxygen on aerosolized Serratia marcescens. Appl. Microbiol. 13,781 .

Leach, R. H. \& ScotT, W. J. (1959). Influence of rehydration on viability of freeze-dried organisms. J. gen. Microbiol. $21,295$.

Lion, M. B. (1963). Quantitative aspects of protection of freeze-dried $E$. coli against the toxic effect of oxygen. J. gen. Microbiol. 32, 321.

MAY, K. R. (1964). Calibration of a modified Andersen bacterial aerosol sampler. Appl. Microbiol. 12, 37.

MAY, K. R. \& HARper, G. J. (1957). The efficiency of various liquid impinger samplers in bacterial aerosols. Br. J. indust. Med. 14, 287.

MCDADE, J. H. \& HALL, L. B. (1964). Survival of gram-negative bacteria in the environment. I. Effect of RH on exposed organisms. Am. J. Hyg. 80, 192.

Mitchell, P. \& Moyse, J. (1956). Osmotic structure and function in bacteria. Symp. Soc. gen. Microbiol. 6, 150.

Monk, G. W. \& McCaffrey, P. A. (1957). Effect of sorbed water on the death rate of washed Serratia marcescens. J. Bact. 73, 85.

Monk, G. W., McCaffrey, P. A. \& Davis, M. S. (1957). Sorbed water killing bacteria. J. Bact. 73, 661.

Record, B. R., Taylor, R. \& Miller, D. S. (1962). The survival of Escherichia coli on drying and rehydration. J. gen. Microbiol. $28,585$.

Silver, I. H. (1965). Viability of micro-organisms using a suspended droplet technique. 1st int. Symp. on Aerobiology, published by the Naval Biological Laboratories, Navy Supply Centre, Oakland, California, U.S.A.

WEBB, S. J. (1959). Factors affecting viability of airborne bacteria 1. Bacteria aerosolized from distilled water. Can. J. Microbiol. 5, 649.

Webs, S. J. (1960). Factors affecting the viability of airborne bacteria. II. The effect of chemical additives on the behaviour of airborne cells. Can. J. Microbiol. 6, 71 .

Zimmerman, L. (1962). Survival of Serratia marcescens after freeze-drying or aerosolization at unfavourable humidity. I. Effects of sugars. J. Bact. 84, 1297. 